\title{
Entomological Survey for CCHF Vectors in Palghar District of Maharashtra
}

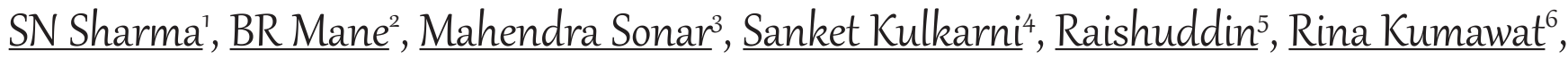 \\ $\underline{\text { Ram Sing }} \underline{h}^{7}, \underline{\text { SK Sing }} \underline{\underline{H}}^{8}$
}

1,4,5,6,7,8 National Centre for Disease Control, Government of India, 22-Sham Nath Marg, Delhi, India.

${ }^{2,3}$ Regional Office for Health \& FW, Governmentof India, Pune, India.

DOI: https://doi.org/10.24321/0019.5138.202103

\section{I $\quad \mathbf{N} \quad \mathbf{F} \quad \mathbf{O}$}

\section{Corresponding Author:}

SN Sharma, National Centre for Disease Control, Government of India, 22-Sham Nath Marg, Delhi, India.

E-mail Id:

drsns.nvbdcp@gmail.com

Orcid Id:

https://orcid.org/0000-0001-8569-1661

How to cite this article:

Sharma SN, Mane BR, Sonar M, Kulkarni S, Raishuddin, Kumawat R et al. Entomological Survey for CCHF Vectors in Palghar District of Maharashtra. J Commun Dis 2021; 53(1): 10-14.

Date of Submission: 2020-12-09

Date of Acceptance: 2021-01-22

\section{$\begin{array}{llllllll}\mathbf{A} & \mathbf{B} & \mathbf{S} & \mathbf{T} & \mathbf{R} & \mathbf{A} & \mathbf{C} & \mathbf{T}\end{array}$}

In view of reports of alert issued by Department of Animal Husbandry, Government of Maharashtra for Crimean Congo Hemorrhagic Fever (CCHF) in Palghar district, a visit was planned from 2-5 October 2020 to assess the situation and vector surveillance of ticks was carried out in the district. There is no past history with any report of $\mathrm{CCHF}$ cases in the district. However, there have been reported outbreaks of dengue and malaria during 2018 \& 2019 as per IDSP data. The department of Animal Husbandry had initiated tick reduction activities in the bordering 19 villages with Gujarat using the chemical compounds (Deltamethrin, Cypermethrin). No confirmed cases of CCHF have been reported in District Palghar so far. During tick surveys in 4 villages and a dairy farm, heavy infestation of Boophilus Sp. (60-70\%) mainly on cows and buffaloes. Hyalomma Sp. (30-40\%) was observed mainly on goats which is the main vector responsible for CCHF. The infected ticks were found to be Boophilus microplus, Hyalomma anatolicum, Hy. marginatum and Rhipicephalus sanguineus species.Guidelines on proper dosage for the formulations of insecticide being used and spray techniques need to be followed up on the animals by the field staff and officials of Animal Husbandry department.

Keywords: Vector, Ticks, CCHF, Surveillance, Zoonotic, Nosocomial, IDSP

\section{Introduction}

Arboviruses, viruses are posing an emerging public health threat and are transmitted by the insect vectors namely mosquitoes, sandflies, ticks, mites and fleas. The study of these vectors and its biology in different geographical areas is quite significant in view of their epidemic and zoonotic potential. The geographical distribution of mosquito-borne diseases such as JE, Dengue, Chikungunya, and Zika has expanded over the last decades. Emerging mosquito-borne viruses that are pathogens for humans and/ or animals are now getting priorities in the health agenda of respective states.

In India, main target mosquitoes posing threats or with potential risk of emergence are Aedes mosquitoes [Aedes aegypti (=Stegomyia aegypti) and Aedes albopictus (=Stegomyia albopicta)]which are responsible for transmission of Dengue virus (DENV) and Chikungunya virus (CHIKV) to humans and Culex vishuni gp.get implicated in 
the transmission of Japanese encephalitis.Other arboviruses are transmitted by hard ticks (e.g. Kyasanur Forest Disease (KFD), Crimean-Congo Hemorrhagic Fever (CCHF) virus by Haemophysalis Spp. and Hyalomma Spp. ticks respectively).

Crimean-Congo Hemorrhagic Fever (CCHF) is a zoonotic viral disease that is asymptomatic in infected animals, but a serious threat to the health of humans. Human infections begin with non-specific febrile symptoms, but progresses to a serious hemorrhagic syndrome with a high case fatality rate. ${ }^{1,2} \mathrm{CCHF}$ is caused by the CCHF virus (CCHFV), a member of the genus Nairovirus in the family Bunyaviridae. The virus is stable for up to 10 days in blood kept at $40^{\circ} \mathrm{C}$. The disease is endemic in many countries in Africa, Europe and Middle East. In India's neighborhood, Pakistan reports 50-60 cases annually. ${ }^{3}$

Although the causative virus is often transmitted by ticks, animal-to-human and human-to-human transmission also occurs. CCHF affects mostly adults (no case has been reported in children under 15 in South Africa since 1993) ${ }^{4}$ and is endemic in many countries in Africa, Europe and Asia. During 2001, cases or outbreaks were recorded in Iran, Pakistan, South Africa with the latest being in India..$^{5}$ It has also been found in parts of Europe including southern portions of the former USSR (Crimea, Astrakhan, Rostov, Uzbekistan, Kazakhstan and Tajikistan), Turkey, Bulgaria, Greece, Albania and Kosovo (a province of the former Yugoslavia). ${ }^{6}$ Limited serological evidence suggests that CCHFV might also occur in parts of Hungary, France and Portugal. The most recent CCHF outbreak occurred in January 2011 in the state of Ahmedabad (India).

CCHF outbreaks constitute a threat to public health because of its epidemic potential, its high case fatality ratio (10$40 \%$ ), its potential for nosocomial (hospital acquired) infection outbreaks and the difficulties in treatment and prevention. ${ }^{7}$ Human beings are the only known host of CCHF virus in which disease is manifested. ${ }^{8}$

Reasons for the outbreak of CCHF in India include climate and anthropogenic factors such as changes in land use, agricultural practices or hunting activities, and movement of livestock that may influence host-tick-virus dynamics. The CCHF virus may infect a wide range of domestic and wild animals. Animal become infected with $\mathrm{CCHF}$ virus from the bite of infected ticks. Domestic ruminant animals, such as cattle, sheep and goats, which act as amplifying host, are viraemic (virus circulating in the bloodstream) for around one week after becoming infected. It does not cause disease in ruminants. Some migratory birds and ostriches are susceptible to $\mathrm{CCHF}$ infection. ${ }^{9} \mathrm{~A}$ number of tick genera are capable of becoming infected with the CCHF virus, but the most efficient and common vectors for CCHF appear to be members of the Hyalomma genus. ${ }^{10}$
CCHF is transmitted mainly by tick vector Hyalommanatolicum, and apart from this by H.marginatummarginatum, H.marginatumrufipes, H.marginatumturanicum and $H$. marginatum isaaci.

Sporadic cases or import cases of CCHF virus (CCHFV) have been reported from Gujarat and Rajasthan recently during 2019. Antibody surveys in domestic animals by ICMR has shown a wide prevalence of CCHF throughout the country.

\section{Material and Methods}

\section{Study Area}

Palghar district is mostly a tribal and coastal district of Maharashtra near Mumbai. The district is having a population of 20.79 lakhs and out of that is $48 \%$ of total population is living in Urbanized Area. The district is having borders of Thane and Nashik districts in the east and northeast and of Valsad district of Gujarat state and the Dadra and Nagar Haveli district of the Dadra and Nagar Haveli and Daman and Diu union territory in the north. The district is also having large geographical area with forests, thick vegetation and cultivation. About 19 villages in two blocks namely Dahanu (4 villages) and Talasari (15 villages) of Palghar district are bordering with Valsad district of Gujarat.

Taluka Dahanu has a human population of 459527 with 1.12 lakh cattle's (buffaloes - 81930, Goat - 30365). Talasari has a population of 186167 with cattle population of 51441 (buffaloes - 39769, Goat - 11672). As per the information from animal husbandry department, about 300-400 large animals (Cows/ buffaloes) and 900-1000 small animals (Goat/Sheep) are transported to Mumbai and other districts through transportation. There may be illegal animals trafficking due to porous borders.

\section{Entomological Surveys}

There has not been any study on the ticks in this district with regard to CCHF vectors. Even, no sero-surveys among animals have been carried out in the district so far. However, it was leant that 3 districts of Maharashtra were taken up by NIV Pune for sero surveillance in animals during 2013 and $4-6 \%$ antibodies for $\mathrm{CCHF}$ were detected in the animal population.

During the visit, 4 villages were selected for tick surveys on the large and small animals. Consent was taken from the house owners for the tick search from their cattle. All safety precautions with PPE were ensured for the survey teams with hand gloves and forceps. The ticks collected were preserved in $70 \%$ ethanol for further identification in the laboratory. The mouth parts, abdomen and legs were taken into consideration as the key taxonomic characters for the identification of ticks. 


\section{Vector Surveillance}

Sampling was undertaken to identify tick habitats, in the bordering villages. Collection of free living ticks - unfed larvae, nymphs and adults by flagging/ drag net method (per man hour density to be recorded). Collection of ticks from domestic and wild animals to determine the tick index and isolation of virus is done from them. Though, it is very difficult to select any site for vector surveillance to detect viral activity through ticks and the infestation rate of ticks among cattle (Sheep, Goat, Cows, Buffalos, Camel) due to their presence across the district with large population density. However, the sample survey was done in four villages.

\section{Result}

During the survey, all types of domestic and pet animals were encountered and searched for tick infestations. Cow, Buffaloes, Goat, Sheep, Horse and dogs were searched for ticks' surveys. Flag/ drag method was also used in these villages for the ticks- unfed larvae/ nymphs or adults. The infected ticks were found to be Boophilus microplus, Hyalomma anatolicum, Hy. marginatum and Rhipicephalus sanguineus species.

Table I.Observations of Tick Surveys using flag/drag method for larval / nymph stages surveys in Palghar

\begin{tabular}{|c|c|c|c|c|c|c|}
\hline $\begin{array}{l}\text { S. } \\
\text { No. }\end{array}$ & Village & $\begin{array}{c}\text { No. of } \\
\text { Flagging/ } \\
\text { dragging net }\end{array}$ & $\begin{array}{c}\text { Nos. positive } \\
\text { with Larvae/ } \\
\text { Nymph }\end{array}$ & $\begin{array}{l}\text { Tick Infestation } \\
\text { rate per flagging/ } \\
\text { drag net }\end{array}$ & $\begin{array}{c}\text { No. of } \\
\text { Nymphs }\end{array}$ & $\begin{array}{l}\text { Density per } \\
\text { flagging/ } \\
\text { dragging net }\end{array}$ \\
\hline 1. & Bori (Talasari) & 20 & 2 & 10 & 3 & 0.15 \\
\hline 2. & Zhahi (Talasari) & 20 & 1 & 5 & 3 & 0.15 \\
\hline 3. & Bordi (Dahanu) & 20 & 5 & 25 & 9 & 0.45 \\
\hline 4. & Therpada (Dahanu) & 20 & 3 & 15 & 5 & 0.25 \\
\hline 5. & Dairy Farm & 10 & 2 & 20 & 2 & 0.25 \\
\hline
\end{tabular}

Table 2.Observations of Tick Surveys undertaken on Cattles in Palghar district

\begin{tabular}{|c|c|c|c|c|c|c|c|c|c|c|}
\hline \multirow[b]{2}{*}{$\begin{array}{l}\text { S. } \\
\text { No. }\end{array}$} & \multirow[b]{2}{*}{ Village } & \multicolumn{4}{|c|}{ No. of Animals } & \multirow{2}{*}{$\begin{array}{l}\text { No. of } \\
\text { Animals } \\
\text { positive } \\
\text { with } \\
\text { Ticks }\end{array}$} & \multirow{2}{*}{$\begin{array}{l}\text { No. of } \\
\text { Ticks } \\
\text { found }\end{array}$} & \multirow{2}{*}{$\begin{array}{c}\text { Tick } \\
\text { Infestation } \\
\text { rate }\end{array}$} & \multirow[b]{2}{*}{$\begin{array}{c}\text { Tick } \\
\text { Index }\end{array}$} & \multirow[b]{2}{*}{ Tick Species } \\
\hline & & Buffalo & Cow & $\begin{array}{l}\text { Goat/ } \\
\text { Sheep }\end{array}$ & $\begin{array}{l}\text { Dog/ } \\
\text { Horse }\end{array}$ & & & & & \\
\hline 1. & $\begin{array}{c}\text { Bori } \\
\text { (Talasari) }\end{array}$ & 52 & 16 & 44 & $1^{*}$ & 42 & 63 & 37.17 & 55.75 & $\begin{array}{c}\text { Boophilus sp./ } \\
\text { Rhiphicephalus } \\
\text { sp. }\end{array}$ \\
\hline 2. & $\begin{array}{c}\text { Zhahi } \\
\text { (Talasari) }\end{array}$ & 20 & 39 & 64 & - & 9 & 36 & 7.31 & 29.3 & Boophilus sp. \\
\hline 3. & $\begin{array}{c}\text { Bordi } \\
\text { (Dahanu) }\end{array}$ & 19 & 11 & - & - & 6 & 26 & 20 & 86.6 & $\begin{array}{c}\text { Hy. anatolicum, } \\
\text { Hy. } \\
\text { marginatum } \\
\text { Rhipicephalus } \\
\text { sanguineus }\end{array}$ \\
\hline 4. & $\begin{array}{l}\text { Therpada } \\
\text { (Dahanu) }\end{array}$ & 28 & 10 & 15 & - & 3 & 4 & 5.6 & 7.5 & Boophilus sp. \\
\hline 5. & $\begin{array}{l}\text { Dairy } \\
\text { Farm }\end{array}$ & - & 12 & - & 3 & 7 & 23 & 46.66 & 153 & $\begin{array}{c}\text { Boophilus } \\
\text { microplus/ } \\
\text { Hyalomma sp. }\end{array}$ \\
\hline & Total & 119 & 88 & 123 & 4 & 67 & 152 & 20.05 & 45.50 & \\
\hline
\end{tabular}


Flagging method was used to observe for the infestation to the number of flag nets during the visit in each village. The number of nymphs was searched and calculated for each flagging. It was observed that the tick infestation rate per flagging/drag net ranged between 5 to 25 per Flag net. However, it was high in the Bordi Village (Dahanu) and Dairy Farm. Density of vector per net varied between 0.15 to 0.45 per flag net. In the Bordi and Therpada villages of Dahanu block. Density of vectors was observed to be high i.e. 0.45 and 0.25 per flag net respectively. While, it was low in the Bori and Zhahi villages of Talasari blocks i.e. 0.15 and 0.15 respectively. In the dairy farm, density was observed as 0.25 per net.

The overall prevalence of ticks during the study period was found to be $60.07 \%$. The most common feeding sites for adult ticks were neck, axilla, belly, groin, udder, perineal regions and tail.

Search was made on the large and small animals in the identified villages for the tick infestations. The overall average infestation rate in five sites has been $20.05 \%$ and the Tick index as 45.50. During surveys, 67 animals were found infested with ticks among the 334 searched. 152 ticks were also collected from the animals searched during the vector surveillance on the cattle.

It was observed that Bori (Talasari) and Bordi (Dahanu) villages have shown high tick index as 55.75 and 86.6, while other two villages namely, Zhahi (Talasari) and Therpada (Dahanu) shown low tick index as 29.3 and 7.5 respectively. However, tick index was observed very high in the dairy farm as 153 .

\section{Discussion}

Ectoparasites, mainly ticks, play an important role in all species of domestic animals and pose greater health concerns and about $80 \%$ of world's cattle population is exposed to tick infestation. ${ }^{11} \mathrm{CCHF}$ is transmitted either through bite of the tick vector, mainly Hyalomma spp., or via direct contact with blood or tissues of viremic animals or humans. ${ }^{12,13}$ Human-to-human transmission is believed to be occurring, although the infectivity of the virus by ordinary contact appears to be very low. ${ }^{14-16}$ History of tick bite, high-risk occupations, having contact with livestock, living in a rural area and older age are risk factors identified by investigators for acquisition of CCHF. ${ }^{17}$ Meat consumption is not usually a risk factor for CCHF. A wide variety of vertebrates like cattle, goats, donkeys, horses, etc., along with smaller wild life species like hares and hedgehogs act as a reservoir for the virus. $1 \mathrm{CCHF}$ has the potential to cause community acquired and nosocomial outbreaks.

During the present vector surveillance, the overall average infestation rate in five sites has been $20.05 \%$ and the Tick index as 45.50. It was observed that Bori (Talasari) and Bordi
(Dahanu) villages have shown high tick index as 55.75 and 86.6, while other two villages namely, Zhahi (Talasari) and Therpada (Dahanu) shown low tick index as 29.3 and 7.5 respectively. However, tick index was observed very high in the dairy farm as 153. The infected ticks were found to be Boophilus microplus, Hyalomma anatolicum, Hy. marginatum and Rhipicephalus sanguineus species.

\section{Recommendations for Prevention \& Control}

- Personal protective measures like avoidance of areas where tick vectors are abundant and when they are active (spring to autumn).

- Use of repellents on the skin (e.g. DEET) and clothing (e.g. permethrin) and wearing gloves or other protective clothing to prevent skin contact with infected tissue or blood.

- When patients with CCHF are admitted to hospital, there is a risk of nosocomial spread of infection. Patients with suspected or confirmed CCHF should be isolated and cared for using barrier nursing techniques.

- Specimens of blood or tissues taken for diagnostic purposes should be collected and handled using universal precautions.

- The approved acaricides by Govt. of India (chemicals intended to kill ticks) may be used as the only a realistic option for well-managed livestock production facilities.

\section{Conflict of Interest: None}

\section{References}

1. Vorou R, Pierroutsakos IN, Maltezou HC. CrimeanCongo hemorrhagic fever. CurrOpinInfect Dis 2007; 20(5): 495-500.

2. Ergönül O. Crimean-Congo hemorrhagic fever. Lancet Infect Dis 2006; 6(4): 203-214.

3. Guidelines for Crimean Congo Hemorrhagic Fever, National Institute of Health, Islamabad, Pakistan. 2008.

4. Crimean-Congo Hemorrhagic Fever. Last Updated: August 20, 2009. Cited 2011 Feb 07. Available from: http://www.cfsph.iastate.edu/Factsheets/pdfs/crime an_congo_hemorrhagic_fever.pdf.

5. Congo fever kills 3 in Gujarat. Cited 2011 Feb 01. Available from: http://www.worldof22.com/2011/01/ india-congo- fever-kills-3-in-gujarat.html.

6. World Health Organization Regional Office for Europe (WHO). Epidemiology for Crimean-Congo hemorrhagic fever virus: Turkey, Russian Federation, Bulgaria, Greece, Albania, Kosovo. Available from: www.euro. who.int/surveillance/outbreaks/20080806_1.

7. World Health Organization. Fact Sheet on CCHF. Available from:http://www.who.int/mediacentre/ factsheets/fs208/en/.

8. Ergonul O. Crimean-Congo hemorrhagic fever. Lancet Infect Dis 2006; 6: 203-214. 
9. James H, Gear S. Crimean Congo Hemorrhagic Fever. SAMJ 1982; 62: 576-580.

10. Pigott DC. CBRNE - Viral Hemorrhagic Fevers.Available from: http://emedicine.Medscape.com/article/830594/ overview. 2009.

11. FAO. Ticks and tick borne disease control. A practical field manual 1. 1984, 1-299.

12. Charrel RN, Attoui H, Butenko AM et al. Tick-borne virus diseases of human interest in Europe. Clin Microbiol Infect 2004;10: 1040-55.

13. Mardani M, Rahnavardi $M$, Rajaeinejad $M$ et al. Crimean- Congo hemorrhagic fever among health care workers in Iran: aseroprevalence study in two endemic regions. Am J Trop Med Hyg 2007; 76: 443-5.

14. Izadi S, Salehi M, Holakouie-Naieni K et al. The risk of transmission of Crimean-Congo hemorrhagic fever virus from human cases to first-degree relatives. Jpn J Infect Dis 2008; 61: 494-6.

15. Saijo M, Tang Q, Shimayi B et al. Possible horizontal transmission of crimean-congo hemorrhagic Fever virus from a mother to her child. Jpn J Infect Dis 2004; 57: 55-57.

16. Izadi S, Naieni KH, Madjdzadeh SR et al. Crimean-Congo hemorrhagic fever in Sistan and Baluchestan Province of Iran, a case-control study on epidemiological characteristics. IntJ Infect Dis 2004; 8: 299-306.

17. Ozkurt Z, Kiki I, Erol S et al. Crimean-Congo hemorrhagic fever in Eastern Turkey: clinical features, risk factors and efficacy of ribavirin therapy. IntJ Infect Dis 2006; 52: 207-215. 